\title{
Abol-Fazl Hasanabadi, Elaheh Mahbub. Introducing the Safavid Documents of the Directorate of Documents and Publications of the Central Library of the Holy Shrine at Mashhad (Iran)
}

Denis Hermann et Colin P. Mitchell

\section{OpenEdition}

\section{Journals}

Édition électronique

URL : http://journals.openedition.org/abstractairanica/40750

DOI : 10.4000/abstractairanica.40750

ISSN : 1961-960X

Éditeur :

CNRS (UMR 7528 Mondes iraniens et indiens), Éditions de l'IFRI

Édition imprimée

Date de publication : 1 décembre 2013

ISSN : 0240-8910

\section{Référence électronique}

Denis Hermann et Colin P. Mitchell, « Abol-Fazl Hasanabadi, Elaheh Mahbub. Introducing the Safavid Documents of the Directorate of Documents and Publications of the Central Library of the Holy Shrine at Mashhad (Iran)», Abstracta Iranica [En ligne], Volume 32-33 | 2013, document 240, mis en ligne le 01 juillet 2016, consulté le 27 septembre 2020. URL : http://journals.openedition.org/abstractairanica/ 40750 ; DOI : https://doi.org/10.4000/abstractairanica.40750

Ce document a été généré automatiquement le 27 septembre 2020.

Tous droits réservés 


\section{Abol-Fazl Hasanabadi, Elaheh Mahbub. Introducing the Safavid Documents of the Directorate of Documents and Publications of the Central Library of the Holy Shrine at Mashhad (Iran)}

Denis Hermann et Colin P. Mitchell

\section{RÉFÉRENCE}

Abol-Fazl Hasanabadi, Elaheh Mahbub. « Introducing the Safavid Documents of the Directorate of Documents and Publications of the Central Library of the Holy Shrine at Mashhad (Iran) ». Iranian Studies, 42/2, 2009, p. 311-327.

1 Il existe jusqu'à présent très peu de publications concernant Mašhad et l'administration gérant le mausolée de l'Emam Rẹ̣ā (m. 818), Āstān-e Qods-e Raḍavī.

2 Cet article très clair est une introduction aux nombreux documents d'époque safavide conservés dans la bibliothèque du mausolée de l'Emām Reḍā à Mašhad. Les AA. soulignent l'importance de ces documents encore méconnus des chercheurs mais précieux pour établir une histoire de l'administration du mausolée et plus largement pour l'histoire administrative, économique et sociale de l'Iran à la période safavide. Le lecteur trouvera de nombreux fac-similés de documents dans l'article. [Compte rendu de Denis Herman]

3 This article was jointly written by a research associate (E. Mahbūb) and the director of documentation (A.F. Ḥasanābādī) at the Bonyād-e Pažūheš-hā-ye Eslāmī-ye Āstān-e Qods-e Radavī in Mašhad. This center's library (located next to the main shrine in Maš 
had and operating under the Directorate of Documents and Publications) has a large number of original documents from the Safavid period about the maintenance of the shrine. Some documents date from the 16th century; but the majority of waqf materials, from the 17th and early 18 th centuries: more than 400,000 documents plus a variety of private collections donated by the Martyr's Foundation, including the Āṣef al-Salțane collection (documents from Qājār Ā Dīn Tehrānī collection (dealing with the shrine under his stewardship as motawalli). Color reproductions of certain Safavid documents figure in the article as well as several tables of statistics and flow charts designed to help readers understood the operations related to revenues (avarajeh), costs (towjihat) and annual stipends (vazifeh) to 'olama of the Āstān-e Qods in Mašhad during the 17th century. [Review of Colin P. Mitchell]

\section{AUTEURS}

\section{DENIS HERMANN}

CNRS, Mondes iranien et indien, Paris

COLIN P. MITCHELL

Dalhousie University, Canada 